\title{
Penggunaan Media Sosial dalam Kesehatan Mental Remaja
}

\author{
Asriyanti Rosmalina ${ }^{1}$, Tia Khaerunnisa ${ }^{2}$ \\ ${ }^{1}$ Program Studi Komunikasi Penyiaran Islam, Fakultas Ushuluddin Adab dan Dakwah, \\ IAIN Syekh Nurjati Cirebon \\ asriyantirosmalina@gmail.com ${ }^{1}$ \\ ${ }^{2}$ Program Studi Bimbingan Konseling Islam, Fakultas Ushuluddin Adab dan Dakwah, \\ IAIN Syekh Nurjati Cirebon \\ tiakhaerunnisa@gmail.com ${ }^{2}$
}

\begin{abstract}
In this sophisticated technology era, people no longer only interact with other people directly, but also people can interact indirectly, namely with the presence of social media technology. In human life, technological developments are always juxtaposed with modernity which is synonymous with progress. Communities nolonger only form communities within an area, but people can form communities with social media. Among the social media users are teenagers. In the use of social media, teenagers usually use it to shareabout their personal activities, such as their stories and photos with their friends. By using social media, someone is free to comment andshare their opinion with other users without any worries. However, inthe use of social media, it is often used to create good feelings, withoutrealizing it, social media can backfire on its users so that it can causebad things. Besides being able to have a strong effect on user behavior,social media can also cause mental health problems for its users.
\end{abstract}

Keywords: Social Media; Mental Health; Adolescents.

\section{PENDAHULUAN}

Sebagai makhluk sosial, manusia hidup tidak bisa sendirian dan membutuhkan orang lain. Menurut Rahman (2013, hlm. 2) mengatakan secara ilmiah, individu mempunyai panggilan untuk selalu hidup bersama orang lain dan berinteraksi. Kebutuhan akan interaksi sosial merupakan kebutuhan dasar yang melekat pada eksistensi manusia. Al-Qur'an menerangkan bahwa sekalipun manusia memiliki potensi fitrah yang selalu menuntut kepada aktualisasi iman dan takwa, namun manusia tidak terbatas dari pengaruh lingkungan atau merupakan agen positif yang tergantung pada pengaruh lingkungan (Anwar, 2014, hlm. 41).

Kondisi psikososisal seseorang dapat dilihat dari lingkungannya, baik di lingkungan rumah, sekolah maupun masyarakat. Kematangan kepribadian seseorang dapat dipengaruhi oleh lingkungan sosial dan perkembangan psikososialnya (Utami, 2017, hlm. 28). 
Psikososial merupakan suatu kondisi yang terjadi pada suatu individu yang mencakup pada aspek psikis dan sosial ataupun sebaliknya. Psikososial merujuk kepada hubungan yang dinamis atau faktor psikis atau sosialnya, yang saling beinteraksi dengan mempengaruhi dari individu satu ke individu lainnya (Chaplin dalam Zubaedi, 2011). Interaksi sosial menggambarkan adanya hubungan-hubungan antara orang peorangan, antara kelompokkelompok manusia, maupun antara orang berorangan dengan kelompok sosial (Aisyah, 2018). Syarat terjadinya interaksi sosial menurut Adi (2012, hlm. 42) merupakan adanya kontak sosial dan komunikasi.

Teknologi telah berkembang pesat, hal tersebut dikarenakan teknologi sudah menjadi kebutuhan primer oleh masyarakat. Perkembangan teknologi tidak dapat dipisahkan dari kehidupan sehari-hari, semua aktivitas keseharian dapat dengan mudah dan cepat dengan bantuan teknologi. Salah satunya dalam bidang informasi dan komunikasi. Komunikasi merupakan suatu proses penyampaian pesan dari seseorang kepada orang lain untuk memberikan informasi atau mengubah sikap, pendapat maupunperilaku dengan melalui lisan ataupun melalui media (Soyomukti, 2012, hlm. 11).

Pada era teknologi yang canggih ini, masyarakat tidak lagi hanya berinteraksi dengan orang lain secara langsung, tetapi juga masyarakat bisa berinteraksi secara tidak langsung, yaitu dengan hadirnya teknologi media sosial. Dalam kehidupan manusia,perkembangan teknologi selalu di sandingkan dengan modernitas yang identik dengan kemajuan. Masyarakat tidak lagi hanya membentuk komunitas di dalam suatu daerah, tetapi masyarakat dapat membentuk komunitas dengan sosial media, seperti BBM, Facebook, Whatsapp dan media sosial lainnya (Febiyanto, 2016, hlm. 11).

Menurut Triyono dkk. (2017) mengatakan bahwa media sosial adalah sebuah teknologi internet yang sukses menumbuhkembangkan interaktivitas. Media sosial bukan lagi sekedar alat penghubung untuk menghantar pesan, bahkan sudah berkembang membentuk jaringan sosial, serta membentuk komunitas kelompok atau grup. Jaringan sosial ini mempunyai pengaruh interaksi yang lebih berkesan dan popular di banding media tradisional atau media lama, seperti media cetak, media elektronik, media siaran dan media interpersonal yang lain. Dengan hadirnya media sosial dapat memudahkan bagi penggunanya untuk berkomunikasi dengan individu lain secara personal bahkan bisa dengan banyak orang. Dengan siapapun, kapanpun dan dimanapun tanpa batas dengan biaya yang lebih murah dibandingkan dengan telepon selama kita masih tersambung dengan koneksi data internet (Moro, 2016).

Pengguna media sosial di antaranya adalah di kalangan para remaja. Dalam penggunaan media sosial, remaja biasanyamenggunakannya untukmembagikan tentang kegiatan pribadinya, seperti curhatannya dan foto-foto bersama temannya. Dengan menggunakan media sosial, seseorang dengan bebas memberikan komentar serta menyalurkan pendapatnya kepada pengguna lain tanpa ada rasa khawatir. Hal tersebut dikarenakan penggunaan media sosial seseorang penggunanya dapat memalsukan dirinya dan juga sangat mudah untuk melakukan tindakan kejahatan. Padahal dalam fase 
perkembangannya, remaja berada dalam fase dimana individu berusaha mencari jati dirinya dengan bergaul bersama teman sebayanya.

Namun pada saat ini, remaja beranggapan bahwa menggunakan media sosial merupakan termasuk orang yang keren dan gaul, dan orang yang tidak berpartisipasi dalam penggunaan media sosial seringkali di klaim sebagai orang yang ketinggalan jaman (Putri dkk., 2016, hlm. 48). Dalam penggunaan media sosial, kerap kali digunakan untuk menimbulkan perasaan baik, tanpa disadari media sosial dapat menjadi bumerang bagi penggunanya, sehingga dapat menimbulkan hal-hal yang bersifat buruk. Selain dapat memberikan efek kuat bagi perilaku penggunanya, media sosial juga dapat menimbulkan masalah pada kesehatan mental pada penggunanya.

\section{PEMBAHASAN}

Media sosial merupakan media internet yang menjadikan pengguna mempresentasikan dirinya maupun berinteraksi, kerjasama, sharing, berkomunikasi dengan pengguna lain dan membentuk ikatan sosial secara virtual (Nasrullah, 2015, hlm. 11). Dalam penelitiannya Kaspani (2019) mengatakan bahwa media sosial merupakan media yang dapat memungkinkan satu atau banyak orang berinteraksi menggunakan teknologi (aplikasi sosial). Interaksi tersebut mencakup saling berkirim pesan, informasi, gagasan, gambar, dan video.

Romel Tea (2004) memisahkan pengertian media online dengan dua kategori sebagai berikut.

1. Media online secara umum

Media online secara umum merupakan suatu jenis atau format media yang dapat diakses melalui jaringan internet yang berisi teks, foto, suara dan video. Media online dapat dimaknai sebagai komunikasi online. Dengan begitu yang termasuk ke dalam media online secara umum adalah, email, BBM, Twiter, Facebook, WhatsApp dan media sosial lainnya.

2. Media online secara khusus

Media online secara khusus merupakan suatu jenis media dalam konteks komunikasi massa. Secara spesifik media secara khusus dapat dimaknai dengan media pers atau media jurnalistik online. Dengan begitu yang termasuk kedalam media online secara khusus adalah portal, radio online, dan tv online.

Pendapat diatas juga diperkuat oleh pendapat Vardiansyah (2004, hlm. 108) yang menyatakan bahwa dapat dikatakan sebagai media massa apabila seseorang mengunjungi sebuah majalah online, sementara ketika seseorang berkirim surat elektronik kepada orang lain (komunikasi online) maka berubah sifatnya menjadi media antar pribadi, yang membedakan adalah tergantuk dari konteks atau sudut padang pengkajinya. Berikut merupakan karakteristik media sosial.

a. Partisipasi 
Media sosial dipahami dapat mendorong seseorang untuk berkontribusi atau media sosial itu sendiri bagi setiap orang. Bahkan media ini seolah-olah menghilangkan batas antara dirinya (media sosial) dengan audiennya.

b. Keterbukaan

Didalam media sosial tentu adanya suatu keterbukaan. Keterbukaan yang dimasudkan diatas adalah diperbolehkannya umpan balik (feedback) atau mengirim saran dan atau komentar antar sesama penggunanya.

c. Perbincangan

Perbincangan dalam media sosial cenderung arus dua arah. Artinya, setiap pengguna dapat menjadi komunikator atau sebaliknya bisa menjadi komunikan bagi mitra komunikasinya. Perbincangan di bagi menjadi dua, yaitu:

1) Akademis, menurut KBBI bahwa akademis berhubungan dengan akademik. Akademis bersifat ilmiah, ilmu pengetahuan, bersifat teori tanpa arti praktis yang langsung. Jadi peneliti dapat menyimpulkan bahwa perbincangan akademis merupakan perbincangan yang bersifat akademi yang berhubungan dengan ilmu pengetahuan, ilmiah, bersifat teori tanpa arti praktis yang langsung.

2) Non akademis, berbeda dengan akademis, yang di mana non akademis ini tidak berhubungan dengan ilmu pengetahuan, teori dan tidak bersifat ilmah. Perbincangan non-akademis melibatkan perbincangan di luar dari ilmu pengetahuan, seperti perbincangan bersifat menghibur, asmara dan sebagainya.

d. Komunitas

Media baru ini dapat dengan mudah untuk membentuk komunitas-komunitas baru, atau sekedar untuk memelihara komunikasi lama. Hal ini di karenakan media sosial menyediakan efsiensi dalam komunikasi untuk mendukung kepentingan-kepentingan komunitas.

Dalam penggunaan media sosial tentu terdapat dampak positif dan juja dampak negatif (Amedie, 2015), yakni sebagai berikut.

1. Dampak Positif

a. Memudahkan seseorang untuk membentuk sebuah komunitas dan dapat mengekspresikan secara bersama melalui media sosial.

b. Dengan perkembangan teknologi yang semakin canggih, perusahaan-perusahaan memanfaatkan media sosial sebagai alat pemasaran dengan bentuk iklan yang sangat menarik.

c. Memudahkan pengguna media sosial tersebut untuk menyebarkan informasi dengan cepat dibandingkan dengan media lama.

d. Media sosial mampu membagikan konten pengguna hanya dengan melalui aplikasi.

e. Memudahkan pengguna media sosial untuk berinteraksi dengan teman atau keluarga tanpa mengenal jarak. 
f. Membantu pengguna untuk mencari informasi mengenai konten-konten yang disukai oleh pengguna lain.

2. Dampak negatif

\section{a. Kecemasan}

Kecemasan yang dimaksud merupakan kecemasan yang dimulai dengan keinginan seseorang untuk mengekspresikan diri yang tidak realistis dan ingin membentuk kesempurnaan yang tidak mampu dilakukan oleh orang tersebut, sehingga menimbulkan kecemasan bagi pengguna.

b. Depresi

Dalam penggunaan media sosial dampak lainnya adalah depresi, dampak ini dipicu oleh kegagalan dalam membentuk sebuah keintiman dengan lawan jenis. Pengguna lebih cenderung ingin menampilkan kesuksesan dibandingkan harus jujur apa adanya dirinya.

c. Aktifitas kriminal

Seseorang yang tidak bertanggung jawab akan menggunakan media sosial sebagai alat untuk menyembunyikan identitas mereka yang sebenarnya. Mereka menggunakan media sosial untuk melakukan berbagai aksi kejahatan seperti cyber bulliying, perdagangan manusia, dan penipuan serta berdagangan obat-obatan terlarang.

Kesehatan mental menurut Darajat (1983) merupakan suatu pengetahuan dan perbuatan yang memiliki tujuan untuk membentuk dan memanfaatkan segala potensi, bakat, pembawaan yang ada dengan semaksimalmengkin, sehingga memberikan kebahagiaan kepada diri sendiri dan orang sekitar dan mampu terhindar dari masalah gangguan penyakit jiwa. Menurut Bernard (1970) (dalam Rosmalina, 2020), kesehatan mental didefinisikan sebagai penyesuaian individu terhadap dirinya sendiri dan lingkungan sekitarnya dengan seefektif mungkin, kebahagiaan, tingkah laku sosial yang positif, serta kemampuan untuk menghadapi dan menerima kenyataan hidup yang dilaluinya.

Dari beberapa definisi tentang kesehatan mental seperti tersebut diatas dapat diambil simpulan:

1) Kesehatan mental dipandang sebagai sesuatu kondisi atau keadaan mental yang sehat.

2) Kesehatan mental dipandang sebagai pengetahuan, perbuatan, bahkan seni untuk mencapai kondisi mental yang sehat.

3) Kesehatan mental dipandang sebagai aktifitas penyesuaian individu untuk memperoleh kondisi mental yang sehat.

Kesehatan mental dipengaruhi oleh beberapa faktor, yaitu faktor internal dan faktor eksternal. Faktor internal merupakan faktor yang berasal dalam diri individu seperti sifat, bakat, hereditas dan lain sebagainya. Sifat contohnya adalah sifat yang lemah lembut, pemarah dan jahat. Bakat contohnya bakat menyanyi, bakat menulis, akting dan lain 
sebagainya. Sementara itu, aspek hereditas seperti turunan emosi, potensi, intelektual dan lain sebagainya. Kemudian, faktor eksternal merupakan faktor yang dipengaruhi dari luar individu. Contohnya lingkungan, hukum, politik, sosial budaya, agama dan pemerintah. Keluarga merupakan lingkungan pertama bagi seseorang yang baru lahir, diantara keluarga tersebut bayi dipengaruhi oleh ibu, ayah, kakek, nenek dan orang-orang yang berada di dekat bayi.

Faktor eksternal yang berada di lingkungan seseorang akan berpengaruh pada kesehatan mental. Lingkungan yang baik akan berpengaruh baik pada kesehatan mental seseorang, sedangkan lingkungan yang buruk akan menciptakan mental yang buruk juga. Penggunaan media sosial merupakan faktor eksternal dari kesehatan mental. Penggunaan media sosial dapat berdampak kepada penggunanya dalam aspek kesehatan mental, diantaranya kecemasan dan depresi.

Kecemasan atau dalam Bahasa Inggris anxiety berasal dari Bahasa Latin "angustus" yang berarti kaku, dan "ango, anci" yang berarti mencekik. Kecemasan (anxiety) dapat diartikan sebagai perasaan khawatir, cemas, gelisah, dan takut yang muncul secara bersamaan, yang biasanya diikuti dengan naiknya rangsangan pada tubuh, seperti jantung berdebar-debar, dan keringat dingin. Kecemasan dapat timbul sebagai reaksi terhadap bahaya, baik yang sungguh-sungguh ada maupun yang tidak atau hanya sekedar imajinasi saja (Rosmalina, 2018, hlm. 125). Kecemasan yang dimaksud merupakan kecemasan yang dimulai dengan keinginan seseorang untuk mengekspresikan diri yang tidak realistis dan ingin membentuk kesempurnaan yang tidak mampu dilakukan oleh orang tersebut, sehingga menimbulkan kecemasan bagi penggunanya.

Media sosial juga seakan-akan menjadi tempat untuk ajang penggunanya untuk mengekspresikan diri dan memamerkan kegiatan sehari-hari. Hal tersebut tentu memunculkan rasa iri pada pengguna lain. Rasa iri tersebut dapat menimbulkan gangguan mental berupa depresi kepada penggunanya. Banyak penggunanya merasa depresi, tertekan, hingga memutuskan untuk bunuh diri karena dipermalukan oleh pengguna lain di media sosial.

Hal lain depresi juga dipicu oleh kegagalan dalam membentuk sebuah keintiman dengan lawan jenis. Penggunalebih cenderung ingin menampilkan kesuksesandibandingkan harus jujur apa adanya dirinya. Dampak lain dari kecemasan dan depresi, yaitu aktifitas kriminal. Seseorang yang tidak bertanggung jawab akan menggunakan media sosial sebagai alat untuk menyembunyikan identitas mereka yang sebenarnya. Mereka menggunakan media sosial untuk melakukan berbagai aksi kejahatan seperti cyber bulliying, perdagangan manusia, dan penipuan serta berdagangan obat-obatan terlarang.

Ada beberapa langkah dalam penanggulan akibat kecanduan media sosial, sebagai berikut:

1. Batasi penggunaan media sosial

Dalam mengatasi kecanduan media sosial, pengguna harus membatasi jumlah waktu yangdigunakan untuk bermainmedia sosial setiap hari dengan menggunakan alarm atau 
stopwatch untuk mengontrol penggunaan media sosial. Ketika pengguna media sosial sudah terbiasa untuk membatasi penggunaan media sosial, maka pengguna mampu mengontrol diri untuk tidak kecanduan pada media sosial. Kemudian alihkan kepada interaksi secara langsung dengan orang lain, seperti keluarga atau teman.

2. Cari informasi lain selain dari media sosial

Media sosial digunakan juga untuk mencari informasi. Apabila tujuan penggunaan media sosial untuk itu, maka beralihlah dalam mencari informasi dari sosial media menjadi membaca koran atau dengan melihat berita di televisi.

3. Mencari kegiatan yang positif

Dalam membatasi penggunaanmedia sosial pengguna perluuntuk mencari kegiatan yang positif. Semakin sibuk seseorang, maka semakin sedikit pula seseorang untuk menggunakan media sosial. Alihkan penggunaan media sosial dengan cara berolahraga atau berkumpul bersama keluarga. Perbanyak aktivitas yang memberikan rasa nyaman pada badan dan juga pada pikiran, bermeditasi, berolahraga, berkelana keluar untuk mencari udara segar atau melakukan aktivitas di luar rumah.

4. Menggunakan media sosial dengan bijak

Membatasi penggunaan media sosial bukan berarti mengurangi beraktivitas menggunakan media sosial menjadikan media sosial sesuatu hal yang negatif. Dalam penggunaan media sosial tentu memiliki manfaat apabila seseorangmenggunakan media sosial tersebut dengan bijak.

5. Lepas dan hapus

Pilihan ini dilakukan apabila seseorang memang benar-benar ingin melepaskan diri dari penggunaan media sosial. Hapus aplikasi dari handphone, kemudian tidak membeli paket data atau tidak menyambungkannya kepada jaringan wifi sehingga intensitas penggunaan media osial akan menjadi berubah.

\section{SIMPULAN}

Teknologi di era teknologi yang canggih ini, masyarakat tidak lagi hanya berinteraksi dengan orang lain secara langsung, tetapi juga masyarakat bisa berinteraksi secara tidak langsung, yaitu dengan hadirnya teknologi media sosial. Media sosial merupakan media internet yang memberikankemudahan pada penggunanyauntuk berinteraksi dengan orang lain dan membentuk sebuah ikatan dengan orang lain secara online atau secara virtual. Selain dapat memberikan efek kuat bagi perilaku penggunanya, media sosial juga dapat menimbulkan masalah pada kesehatan mental. Di antaranya adalah gangguan kecemasan dan depresi sehingga menjadikan kesehatan mental penggunanya menjadi terganggu. Namun ada cara untuk menanggulangi kecanduan media sosial, dengan cara membatasi penggunaan media sosial, mencari informasi selain dari media sosial, mencari kegiatan yang positif, menggunakan media sosial dengan bijak, lepas dan hapus aplikasi media sosial. 
56 | Rosmalina, Khaerunnisa - Penggunaan Media Sosial ...

Dengan demikian efek dari penggunaan media sosial menjadi menurun terhadap kesehatan mental penggunanya.

\section{DAFTAR PUSTAKA}

Adi, Rianto. (2012). Sosiologi Hukum. Jakarta: Yayasan Pustaka Obor Indonesia.

Aisyah, Siti. (2018). "Pengaruh Pemanfaatan WhatsApp Terhadap Interaksi Anak dan Orang Tua Peserta Didik SMPN 10 Pontianak”. Jurnal. Pontianak. Universitas Tanjungpura Pontianak.

Amedie, J. (2015). The Impact Of Social Media on Society. Advanced Writing: Pop Culture Interesections, 2.

Anwar, M. F. (2014). Landasan Bimbingan dan Konseling Islam. Yogyakarta: Deepublish.

Darajat, Zakiyah. 1983. Peran Agama dalam KesehatanMental (Cet: VII). Jakarta:Penerbit Gunung Agung.

Febyanto, Chandy. (2016). “Analisis Pengaruh Kelompok Sosial Dan Keluarga Terhadap Perkembangan Psikososial Anak (Studi Kasus Pada Siswa SDN Wonokerso 01 Kabupaten Malang”. Jurnal Pendidikan Dasar Nusantara. 2 (1). 11.

Haniza, N. (2019). Pengaruh Media Sosial terhadapPerkembangan Pola Pikir, Kepribadian dan KesehatanMental Manusia. J. Komun.

Kaspani, Anan. 2019. "Pengaruh Media Sosial WhatsApp Sebagai Media Silaturahim Mahasiswa Komunikasi Penyiaran Islam IAIN Syekh Nurjati Cirebon Angkatan Tahun 2015”. Skripsi. Cirebon: Program Sarjana IAIN Syekh Nurjati Cirebon.

Moro, H, K, E, P. (2016). Pengaruh Penggunaan WhatsApp Messenger Terhadap Prestasi Blajar Mahasiswa Kelas KKH di PBIO FKIP UAD. Universitas Ahmad Dahlan. Jurnal Pendidikan.

Putri, W. S. R., Nurwati, N., \& Budiarti, M. (2016). Pengaruh media sosial terhadap perilakuremaja. Prosiding Penelitiandan Pengabdian kepada Masyarakat, 3(1).

Rahman, Agus A. (2013). Psikologi Sosial: Integrasi Pengetahuan Wahyu dan Pengetahuan Empirik. Jakarta: RajaGrafindo Persada.

Romel Tea. 2004. https://romeltea.com/media-online-pengertian-dan-karakteristik/. (diakses pada tanggal 09 Mei 2019).

Rosmalina, Asriyanti. 2018. Bimbingan Konseling Islam Dalam Kesehatan Mental.Cirebon. Elsi Pro.

Soyomukti, $\quad$ Nurani. 2012. Pengantar Ilmu Komunikasi. Yogyakarta: Ar-Ruzz Media.

Triyono, Agus, dkk. (2017). Komunikasi Religi, dan Budaya. Yogyakarta: Asosiasi Pendidikan Ilmu Komunikasi Perguruan Tinggi Muhammadiyah (APIK PTM). 
Utami, Wuri, dkk. (2017). Hubungan Tipe Pola Asuh Orang Tua Dengan Perkembangan Psikososial Anak Usia Prasekolah Di TK Pertiwi 1 Desa Purbowangi Kecamatan Buayan Kabupaten Kebumen. Stikes Muhamadiah Gombong. Jurnal Ilmiah Kesehatan Keperawatan. 2017: 13 (1); 27.

Zubaedi. (2011). Desain Pendidikan Karakter. Jakarta: Kencana. 
58 | Rosmalina, Khaerunnisa - Penggunaan Media Sosial ... 